\title{
Yes, we did fail Bongani Mayosi
}

Nonhlanhla Khumalo, wife of Bongani Mayosi, paid this tribute to him at his funeral.

The Harvard Business School offers a prestigious Advanced Management Program. This Program aims to 'empower senior executives with the analytical skills and cross-functional perspective to drive performance across domains, industries, and borders'. Bongani attended the Program (which he called 'an MBA on steroids') during his sabbatical leave from the University of Cape Town (UCT) in 2016. He was part of a class of over 150 chief executive officers and other top executives from more than 20 countries. When I heard that this distinguished class had chosen Bongani to be the valedictorian to give the graduation speech, I said to him 'Hayi Rhadebe it is clear, the whole world agrees that you are exceptionally smart.' He smiled and with that twinkle in his eyes said 'Bonanje mfazi these are all clever business people, the only reason they chose me was because I was brave enough to ask stupid questions.'

Such was the humility of Bongani Mayosi, who I first met when I sat next to him in a bus on the first Friday of orientation at the then University of Natal Medical School in January 1983. At the time he was only 16 years old, having achieved the highest marks in the matric examinations of the Independent Transkei at the tender age of 15. Indeed, our conversation started on that tour bus and ended 35 years later on that catastrophic day of 27 July 2018.

When I met Bongani, I was an idealistic, conservative 17-year-old girl who believed that having a boyfriend at university could put my academic success at risk. But in spite of my resolve, I found Bongani's charm, humour and intelligence irresistible. Our daughters once asked me how he had proposed to me. No doubt they were thinking of a romantic setting, flowers, and ring held out with him on bended knee! They laughed when I told them that I don't even remember where we were: he simply asked what the lobola process was in my family. In fact, he asked about lobola (the process of asking a family for a bride's hand in marriage) not once but twice. First when he was 18 and I 19 years old; at that time my mother expressed displeasure, adding that ‘... you went to university to get a degree, get the degree first then talk about getting married. The second time was when we were more mature, aged 22 and 23 years, with our graduation a few weeks away - and our parents could no longer refuse.

I have had the privilege of watching very closely Bongani's unique handling of various situations. He was delighted at becoming a father for the first time. But when I suggested a second child, he asked why anyone would chose to write the same examination twice implying that the pregnancy and birth were like an exam! In spite of this, he did agree to a second child, who became the apple of his eye. He also relished the opportunity to adopt a teenage girl when so many would shy away from such a prospect. With no unfulfilled desire for a son, he demonstrated selfless love to his daughters and inspired self-confidence in them and in the many girls who called him Uncle Bongani and spent countless weekends at our home.

Every beggar who approached Bongani would be spoken to with respect. However, how much money they got depended on what they said: they got just a few coins if their request was nonspecific. I can't tell how many times I anxiously watched Bongani open his wallet, exposing all his money, to give away the exact ten or twenty rands he was asked for. Interestingly, not once did anyone grab the wallet and run. I think the beggars were so surprised by his kind response to them on these occasions that stealing from him was not an option.

I have watched his excitement at the discovery of potential in a student and his search for funding to develop it. When so many of his comrades in the 1990s personally gained company shares from 'black economic empowerment' initiatives and became wealthy, Bongani was instrumental in motivating that these shares should rather be used to establish various funding streams for clinicians to do PhDs. He talked often about the need for a critical mass of the brightest African clinician scientists to solve Africa's health problems.

Much has been spoken and written about Bongani's achievements. One little-known fact is that when we were in Oxford as a young family, he and I entered the inter-college Cuppers Competition for dance sport as part of the Wolfson College team. We danced the 'quick step' and, yes, we were the only couple that had children in the audience. Our daughters were screaming our number ' 119 ' at the tops of their little lungs. The Wolfson College dance team made history that day by winning the Cuppers for the first time ever. I suspect that the screams of innocent children won the day for us. Bongani would update his $\mathrm{CV}$ with the entry of this win that night and refuse to go to further dance classes. When I protested, he simply asked whether there was any chance that we could achieve a higher accolade in ballroom dance. When I said no, he smiled and gave me a hug before moving on to something else.

In recent months some have spoken about Bongani's inability to cope with administration. Let's not forget that in order to fulfil his many national and international roles, to achieve the meteoric rise in the number of publications, the amount of funding and staff compliments during his 10-year tenure as Head of the Department of Medicine, Bongani had to be a pretty good administrator. He was not satisfied with his excellent achievements in medicine. He returned from Harvard refreshed and enthusiastic with a vision for the faculty.

Bongani, you could not have been ready for what awaited you. Before you could develop a relationship with your team, within the first week of your deanship your office was occupied by protesting students. They sent lists of demands and messages to your private cell phone at all hours of the day and night. I watched you increasingly lose sleep and become edgy. It was not so much what they called you but how they made you feel. Children you cared for deeply treated you as an enemy. 'Staff for social justice' alienated you in a popularity contest you never signed up for, as if your entire being was not for justice. Senior academics criticised and blamed you, as if your very heart did not beat for academic excellence. Something in you shifted. The university neglected you, and when you tried to leave used your high sense of duty, encouraging you to stay. Maybe if your request for sabbatical leave had been processed in time things would have been different. I remember that when you started counselling, you asked that I should come in and we were advised that only the patient was counselled. A case should be made for the next of kin to be present in counselling sessions (as long as the patient consents). Inclusion might have helped me get a better sense of how severe the depression was. I know now that you hid most of your pain from me. I am so sorry - I too failed you Bongani, so busy and excited with my own projects. And on that last day I hurried off without lingering when I kissed your soft lips or looking into your eyes ... 
I can't remember the sad occasion, but Bongani once told me a story that as children he and his brother Sipho were once sent to fetch milk that they both carried in a large container. He said he did not remember how the milk got spilt, but they helplessly watched it sink into the soil. They were horrified, and afraid of the consequences. He then ended by saying 'Don't cry over spilt milk, Nhlanhla, instead learn from the experience to make sure it does not happen again. He would mention the spilt milk analogy over the years as a useful tool to move one from the paralysis of regret.

When he was born he was called Bongani Mawethu. Bongani means 'give thanks' and Mawethu means 'our community'. When he became a man he was called Jongilizwe, one who looks after the nation or the world. Bongani fulfilled the prophesies of his names. He had a genuine interest in people, all people - just look at his research group and the many who love him the world over.
Bongani was a 'servant leader' who lived out his love for us. If we really want to perpetuate his legacy, we will find ways to fund the production of a critical mass of highly skilled African clinician scientists to solve Africa's health problems. We will find 'our community spirit', 'the Mawethu Spirit', in us. This is the spirit that says 'I see you, I acknowledge you and even when I disagree with you I will not insult or humiliate you.' While there may be many academic lessons, the 'Mawethu Spirit' is to me the core human lesson from Bongani Mayosi's kind, positive, enthusiastic and generous life.

Bongani did not have a mean bone in his body. He was not vindictive or judgmental, and forgiveness came spontaneously to him.

Yes, we did fail Bongani Mayosi. Let's emulate his example as a tribute. Let's embrace 'the Mawethu Spirit'.

As we leave this place:

Let us calmly reflect and learn

Let us forgive each other and ourselves,
Let us commit to fight injustice and division

Let us lift as we rise so that we can soar the heights of excellence - as UCT, South Africa, Africa and the world.

Let us embrace the Mawethu Spirit: I see you, I hear you

Even when I disagree

I will not insult or humiliate you All humans, even the brightest

Have fragile spirits that thrive when respected

I will respect your humanity

I will lift even when I want to rise.

Lala ngoxolo eNkosini sithandwa sami Rest in the Lord's peace my love

\section{Nonhlanhla Khumalo Mayosi}

University of Cape Town, South Africa

S Afr Med J 2018;108(9):697-698. DOI:10.7196/ SAMJ.2018.v108i9.13609

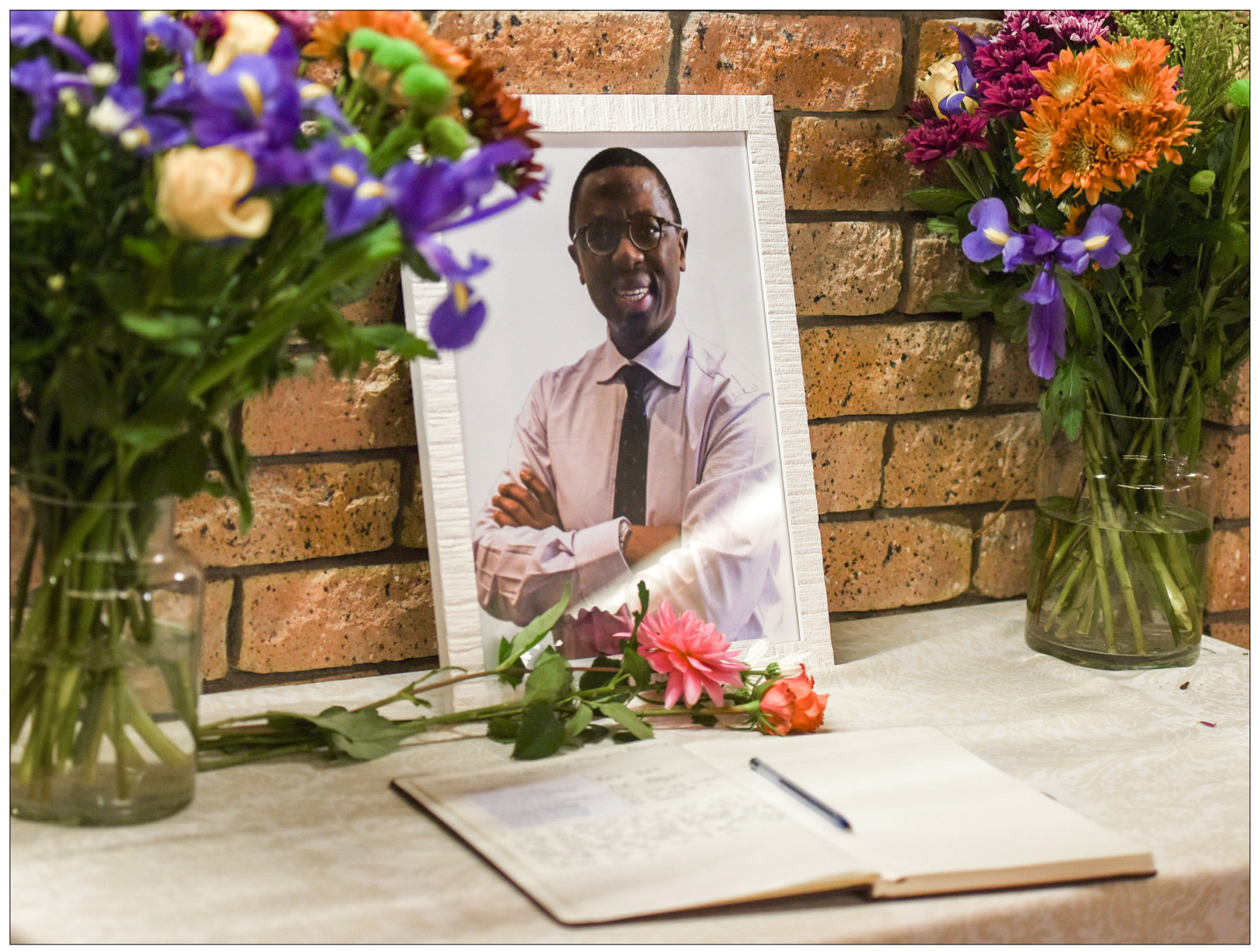

